\title{
Using Microkinetic Analysis to Search for Novel Anhydrous Formaldehyde Production Catalysts
}

\author{
Han-Jung Li, ${ }^{a}$ Adam C. Lausche, ${ }^{a}$ Andrew A. Peterson, ${ }^{b}$ Heine A. Hansen, ${ }^{c}$ Felix Studt, ${ }^{a}$ \\ and Thomas Bligaard ${ }^{\mathrm{a} *}$ \\ ${ }^{a}$ SUNCAT Center for Interface Science and Catalysis, SLAC National Accelerator \\ Laboratory, 2575 Sand Hill Road, Menlo Park, CA 94025, USA and Department of \\ Chemical Engineering, Stanford University, Stanford, CA 94305, USA \\ ${ }^{\mathrm{b}}$ School of Engineering, Brown University, Providence, RI 02912, USA \\ ${ }^{c}$ Department of Energy Conversion and Storage, Technical University of Denmark, \\ Frederiksborgvej 399, DK-4000, Denmark
}

* Corresponding author: bligaard@ @stanford.edu, phone: +1 (650) 926-2716

\section{Keywords:}

Methanol, Formaldehyde, Heterogeneous catalysis, Density functional theory, Scaling relations, Microkinetic model 


\begin{abstract}
Direct dehydrogenation of methanol to produce anhydrous formaldehyde is investigated using periodic density functional theory (DFT) and combining the microkinetic model to estimate rates and selectivities on stepped (211) surfaces under a desired reaction condition. Binding energies of reaction intermediates and transition state energies for each elementary reaction can be accurately scaled with $\mathrm{CHO}$ and $\mathrm{OH}$ binding energies as the only descriptors. Based on these two descriptors, a steady-state microkinetic model is constructed with a piecewise adsorbate-adsorbate interactions model that explicitly includes the effects of adsorbate coverage on the rates and selectivities as well as the volcano plots are obtained. Our results show that most of the stepped (211) pure-metallic surfaces such as $\mathrm{Au}, \mathrm{Pt}, \mathrm{Pd}, \mathrm{Rh}, \mathrm{Ru}, \mathrm{Ni}, \mathrm{Fe}$, and $\mathrm{Co}$ are located in a region of low activity and selectivity towards $\mathrm{CH}_{2} \mathrm{O}$ production due to higher rate for $\mathrm{CH}_{2} \mathrm{O}$ dehydrogenation than $\mathrm{CH}_{2} \mathrm{O}$ desorption. The selectivities toward $\mathrm{CH}_{2} \mathrm{O}$ production on $\mathrm{Zn}, \mathrm{Cu}$, and $\mathrm{Ag}$ surfaces are located on the boundary between the high and low selectivity regions. To find suitable catalysts for anhydrous $\mathrm{CH}_{2} \mathrm{O}$ production, a large number of $\mathrm{A}_{3} \mathrm{~B}$-type transition metal alloys are screened based on their predicted rates and selectivities, as well as their estimated stabilities and prices. We finally propose several promising candidates for the dehydrogenation of $\mathrm{CH}_{3} \mathrm{OH}$.
\end{abstract}




\section{Introduction}

Formaldehyde $\left(\mathrm{CH}_{2} \mathrm{O}\right)$ production from methanol is of considerable interest because $\mathrm{CH}_{2} \mathrm{O}$ is an important intermediate in the production of a large number of industrial chemicals, such as plastics, resins, and explosives [1]. Recently, anhydrous $\mathrm{CH}_{2} \mathrm{O}$ has gained increased attention because of its important applications, such as the production of high polymeric polyoxymethylene, solid $\mathrm{CH}_{2} \mathrm{O}$, polyacetal resin, agricultural chemicals, and medical intermediates [2]. Generally, $\mathrm{CH}_{2} \mathrm{O}$ can be obtained from oxidative or nonoxidative methanol dehydrogenation by the following processes [3]:

$$
\begin{array}{ll}
2 \mathrm{CH}_{3} \mathrm{OH}+\mathrm{O}_{2} \leftrightarrow 2 \mathrm{CH}_{2} \mathrm{O}+2 \mathrm{H}_{2} \mathrm{O} & \Delta_{f} \mathrm{H}^{\mathrm{o}}=-298.8 \mathrm{~kJ} / \mathrm{mol} \\
2 \mathrm{CH}_{3} \mathrm{OH}+\frac{1}{2} \mathrm{O}_{2} \leftrightarrow 2 \mathrm{CH}_{2} \mathrm{O}+\mathrm{H}_{2} \mathrm{O}+\mathrm{H}_{2} & \Delta_{f} \mathrm{H}^{\mathrm{o}}=-57 \mathrm{~kJ} / \mathrm{mol} \\
\mathrm{CH}_{3} \mathrm{OH} \leftrightarrow \mathrm{CH}_{2} \mathrm{O}+\mathrm{H}_{2} & \Delta_{f} \mathrm{H}^{\mathrm{o}}=92.4 \mathrm{~kJ} / \mathrm{mol}
\end{array}
$$

The majority of $\mathrm{CH}_{2} \mathrm{O}$ production is at present achieved through the catalytic partial oxidation of methanol in air over an $\mathrm{Fe}_{2} \mathrm{O}_{3}-\mathrm{MoO}_{3}$ or silver catalyst, which produces $40 \%$ $\mathrm{CH}_{2} \mathrm{O}$ in aqueous solution [4]. However, in this process a significant fraction of the reactant stream is wasted in producing by-products: large amounts of $\mathrm{H}_{2} \mathrm{O}, \mathrm{CO}$, and dimethyl ether, as well as small amounts of $\mathrm{CO}_{2}$ and formic acid [5]. This is further complicated by the formation of an azeotrope, which makes it costly to remove $\mathrm{H}_{2} \mathrm{O}$ from the aqueous $\mathrm{CH}_{2} \mathrm{O}$ product stream [6]. Non-oxidative dehydrogenation of $\mathrm{CH}_{3} \mathrm{OH}$, therefore, represents one strategy to not only produce anhydrous $\mathrm{CH}_{2} \mathrm{O}$ but also to potentially reduce the waste of $\mathrm{CH}_{3} \mathrm{OH}$ [4].

Ruf et al. experimentally reported that without any catalyst, methanol could dehydrogenate to anhydrous $\mathrm{CH}_{2} \mathrm{O}$ at a very high temperature, $1173 \mathrm{~K}$, with a $\mathrm{CH}_{2} \mathrm{O}$ yield being less than $20 \%$ and only $43 \%$ selective towards formaldehyde [7]. Anhydrous $\mathrm{CH}_{2} \mathrm{O}$ production from non-oxidative $\mathrm{CH}_{3} \mathrm{OH}$ dehydrogenation has been investigated on bulk and supported $\mathrm{Ag}, \mathrm{Zn}, \mathrm{Cu}$, and $\mathrm{Au}$ catalysts [8-16], however, these catalysts were shown to deactivate a few hours. For instance, experimental work by Yamamoto et al. reported that, a P-promoted $\mathrm{CuO} / \mathrm{SiO}_{2}$ catalyst with $50 \% \mathrm{CH}_{3} \mathrm{OH}$ conversion and $80 \% \mathrm{CH}_{2} \mathrm{O}$ selectivity, was partially deactivated over the course of $4 \mathrm{~h}$, possibly due to sintering [9]. Ren et al. also showed that although a $\mathrm{AgO} / \mathrm{SiO}_{2} / \mathrm{MgO} / \mathrm{Al}_{2} \mathrm{O}_{3}$ catalyst could yield $100 \%$ $\mathrm{CH}_{3} \mathrm{OH}$ conversion and $100 \% \mathrm{CH}_{2} \mathrm{O}$ selectivity at $873 \mathrm{~K}$, the overall conversion decreased to $10 \%$ after only a few hours because of the reduction of the active $\mathrm{AgO}$ phase to inactive $\mathrm{Ag}$ [12]. Similarly, the non-oxidative $\mathrm{CH}_{3} \mathrm{OH}$ dehydrogenation processes have also been reported with $62 \% \mathrm{CH}_{2} \mathrm{O}$ selectivity on mica- or zeolite-supported $\mathrm{ZnO}$ catalysts, where $\mathrm{CH}_{2} \mathrm{O}$ production rates decreased with time due to the reduction of active $\mathrm{ZnO}$ to inactive $\mathrm{Zn}$ metal $[17,18]$. Generally, the reductive environment inherent to $\mathrm{CH}_{3} \mathrm{OH}$ dehydrogenation causes oxygen-containing catalysts to deactivate quickly [5]; 
therefore, a highly capable catalyst for the dehydrogenation of $\mathrm{CH}_{3} \mathrm{OH}$ is needed.

Although the non-oxidative dehydrogenation of $\mathrm{CH}_{3} \mathrm{OH}$ attracts considerable interest because of the significant market for anhydrous formaldehyde, currently available catalysts are still unsatisfactory. Previous work by Lausche et al. combined density functional theory calculations with microkinetic modeling to provide a framework for understanding the trends in activity and selectivity for methanol dehydrogenation on stepped (211) sites of transition metal surfaces [19]. Generally, the more open surfaces are more active, which has been shown to give a reasonable correlation with experiments in a number of previous studies. In the present work, we have employed the same strategies to study anhydrous $\mathrm{CH}_{2} \mathrm{O}$ production. However, in order to accurately scale large intermediates such as $\mathrm{CH}_{2} \mathrm{OH}, \mathrm{CHOH}$, and $\mathrm{CH}_{2} \mathrm{O}$, we use the binding energies of $\mathrm{CHO}\left(\mathrm{E}_{\mathrm{CHO}}\right)$ and $\mathrm{OH}\left(\mathrm{E}_{\mathrm{OH}}\right)$ as descriptors rather than the binding energies of $\mathrm{C}\left(\mathrm{E}_{\mathrm{C}}\right)$ and $\mathrm{O}\left(\mathrm{E}_{\mathrm{O}}\right)$. In addition, we have considered adsorbate-adsorbate interactions using a piecewise model, previously reported by Khan et al. [20], to take into account the effects of adsorbate coverage on the rates and selectivities. One promising possibility is to use bimetallic alloys as catalysts, which have unique physical and chemical properties that differ from those of the pure metals. We have thus used our microkinetic model based on the pure metals to screen a large number of transition metal alloys based on their predicted rates and selectivities, as well as their estimated stabilities and prices. Finally we propose several candidates for the dehydrogenation of $\mathrm{CH}_{3} \mathrm{OH}$.

\section{Methods}

\subsection{Density Functional Theory Calculations}

All the binding energies of surface intermediates and transition states for the $\operatorname{Ag}(211)$, $\mathrm{Cu}(211), \operatorname{Pd}(211), \operatorname{Pt}(211)$, and $\mathrm{Rh}(211)$ surfaces were taken from previously published works [19] and CatApp [21,22]. All other electronic structure calculations were performed using the DACAPO [23] plane wave code using the RPBE exchangecorrelation functional [24]. We note here that RPBE yields similar energies for all intermediates involved in this study when compared to BEEF-vdW [25,26], a functional that specifically treats vdW interactions [27]. Face-centered cubic surfaces $(\operatorname{Fcc}(211))$ were modeled by nine-layer slabs with a unit cell size of $(1 \times 3)$. An energy cutoff of 340

and a density cutoff $500 \mathrm{eV}$ were used, and a Monkhorst-Pack k-point grid of density $4 \times$ $4 \times 1$ was used to sample the Brillouin zones.

\subsection{Microkinetic Modeling}


In this work, the adsorption energies of $\mathrm{C}_{\mathrm{x}} \mathrm{H}_{\mathrm{y}} \mathrm{O}$ intermediates and transition states can be scaled linearly with the adsorption energies of $\mathrm{CHO}^{*}$ and/or $\mathrm{OH}^{*}$, and the details of scaling relations for intermediates and transition states are described in the section 1 and 2 of the supplementary information, along with the fitting parameters of all the scaling relations. All the parameters of the microkinetic model were performed as described in Section 3 of the supplementary information. The steady-state numerical solutions to the microkinetic model were obtained assuming a $0.1 \%$ approach to equilibrium $(95 \%$ $\mathrm{CH}_{3} \mathrm{OH}, 1 \% \mathrm{CH}_{2} \mathrm{O}, 1 \% \mathrm{CO}$, and $3 \% \mathrm{H}_{2}$ ) at $823 \mathrm{~K}$ and 1 bar to achieve reasonable rates and simulate reactor operation under differential conditions [28].

A piecewise adsorbate-adsorbate interaction model was included in the microkinetic model, which was previously reported by Khan et al. [20]. The adsorbate-adsorbate interaction effects were calculated by calculating the change in adsorption energy at various coverages. At the stepped (211) surface coverages above the threshold coverage, $\theta^{0}=0.5 \mathrm{ML}$, adsorption energies of adsorbates decreased linearly, while the change in the adsorption energy was negligible for surface coverages below this value, similar to results described elsewhere [29,30]. As described in reference [29], three different adsorption sites, step (s), four-fold (f), and terrace (t) were included in a stepped (211) surface. All of the intermediates in this work preferentially adsorbed at the step site over the other sites. In addition, the presence of under coordinated sites such as the step sites have been shown to be particularly important for catalytic activity of the metal nanoparticles for different catalytic processes [31]. Therefore, we performed an interaction model, which assumed that all reaction intermediates were preferentially adsorbed at step sites and are present in negligible amounts at the other sites. Further details of the adsorbate-adsorbate interaction model and the linear scaling parameters used in this work are shown in section 4 of the supplementary information.

\section{Results and discussions}

\subsection{Microkinetic Modeling}

The 13 elementary steps for the $\mathrm{CH}_{3} \mathrm{OH}$ dehydrogenation process are shown below:

$$
\begin{aligned}
& \mathrm{CH}_{3} \mathrm{OH}_{(\mathrm{g})}+2^{*} \leftrightarrow \mathrm{CH}_{3} \mathrm{O}^{*}+\mathrm{H}^{*} \\
& \mathrm{CH}_{3} \mathrm{OH}_{(\mathrm{g})}+2^{*} \leftrightarrow \mathrm{CH}_{2} \mathrm{OH}^{*}+\mathrm{H}^{*} \\
& \mathrm{CH}_{3} \mathrm{O}^{*}+* \leftrightarrow \mathrm{CH}_{2} \mathrm{O}^{*}+\mathrm{H}^{*} \\
& \mathrm{CH}_{2} \mathrm{OH}^{*}+* \leftrightarrow \mathrm{CHOH}^{*}+\mathrm{H}^{*} \\
& \mathrm{CH}_{2} \mathrm{OH}^{*}+* \leftrightarrow \mathrm{CH}_{2} \mathrm{O}^{*}+\mathrm{H}^{*}
\end{aligned}
$$




$$
\begin{aligned}
& \mathrm{CH}_{2} \mathrm{O}^{*}+* \leftrightarrow \mathrm{CHO}^{*}+\mathrm{H}^{*} \\
& \mathrm{CHOH}^{*}+* \leftrightarrow \mathrm{COH}^{*}+\mathrm{H}^{*} \\
& \mathrm{CHOH}^{*}+* \leftrightarrow \mathrm{CHO}^{*}+\mathrm{H}^{*} \\
& \mathrm{CHO}^{*}+* \leftrightarrow \mathrm{CO}^{*}+\mathrm{H}^{*} \\
& \mathrm{COH}^{*}+* \leftrightarrow \mathrm{CO}^{*}+\mathrm{H}^{*} \\
& \mathrm{CH}_{2} \mathrm{O}^{*} \leftrightarrow \mathrm{CH}_{2} \mathrm{O}(\mathrm{g}) \\
& \mathrm{CO}^{*} \leftrightarrow \mathrm{CO}_{(\mathrm{g})}+* \\
& 2 \mathrm{H}^{*} \leftrightarrow \mathrm{H}_{2(\mathrm{~g})}+2^{*}
\end{aligned}
$$

The free energy diagram for $\mathrm{CH}_{3} \mathrm{OH}$ dehydrogenation to $\mathrm{CH}_{2} \mathrm{O}, \mathrm{CO}$, and $\mathrm{H}_{2}$ on a stepped $\mathrm{Cu}$ (211) surface is depicted in Fig. 1. From the free energy diagram, there are two possible reaction pathways for $\mathrm{CH}_{3} \mathrm{OH}$ dehydrogenation: through the $\mathrm{O}-\mathrm{H}$ bond scission of $\mathrm{CH}_{3} \mathrm{OH}$ to form a $\mathrm{CH}_{3} \mathrm{O}$ intermediate or through the $\mathrm{C}-\mathrm{H}$ bond scission of $\mathrm{CH}_{3} \mathrm{OH}$ to form a $\mathrm{CH}_{2} \mathrm{OH}$ intermediate in the first step.

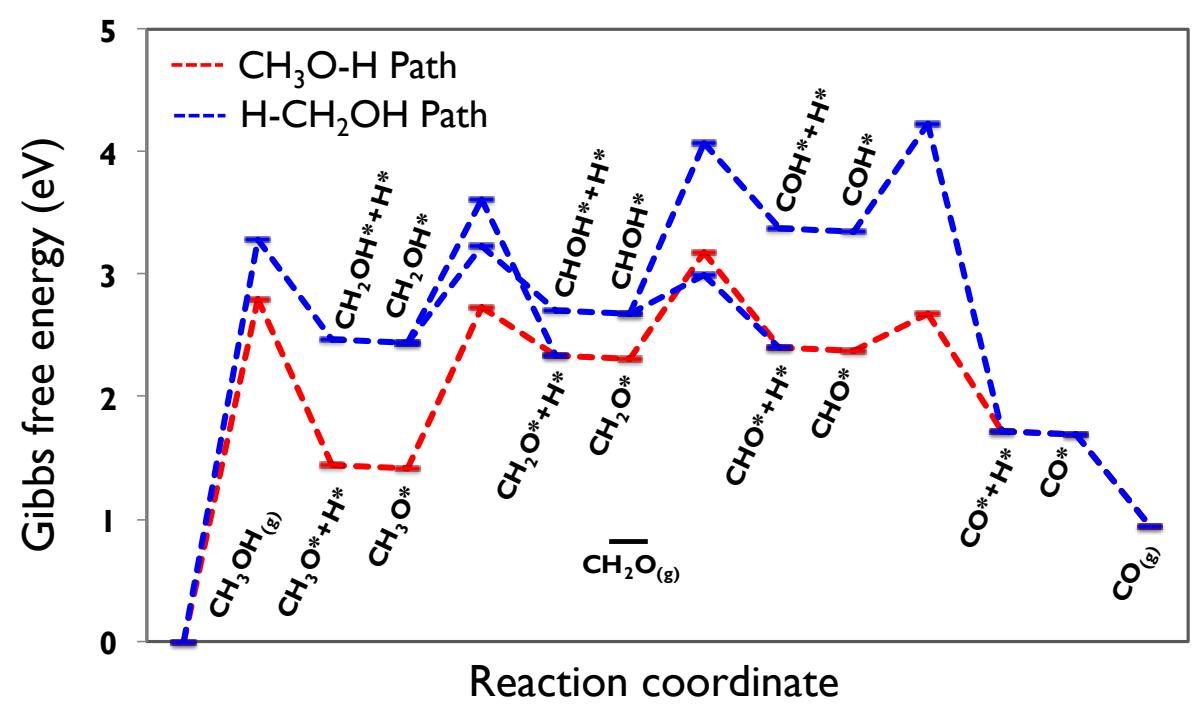

Fig. 1. Free energy diagram for $\mathrm{CH}_{3} \mathrm{OH}$ dehydrogenation to $\mathrm{CH}_{2} \mathrm{O}, \mathrm{CO}$, and $\mathrm{H}_{2}$ on a $\mathrm{Cu}(211)$ surface. Reaction conditions are: $\mathrm{T}=823 \mathrm{~K}, \mathrm{P}=1$ bar, with a gas composition of $95 \% \mathrm{CH}_{3} \mathrm{OH}, 1 \% \mathrm{CH}_{2} \mathrm{O}, 1 \% \mathrm{CO}$ and $3 \% \mathrm{H}_{2}$.

The volcano plots for calculated turnover frequencies (TOFs) for $\mathrm{CH}_{3} \mathrm{OH}$ decomposition starting from $\mathrm{O}-\mathrm{H}$ or $\mathrm{C}-\mathrm{H}$ bond scissions of $\mathrm{CH}_{3} \mathrm{OH}$ are shown in Fig. 2. These plots are shown without ( $\mathrm{a}$ and $\mathrm{b}$ ) and with ( $\mathrm{c}$ and $\mathrm{d}$ ) adsorbate-adsorbate interactions. Comparing the volcano plots of $\mathrm{O}-\mathrm{H}$ (Fig. 2(c)) and $\mathrm{C}-\mathrm{H}$ (Fig. 2(d)) bond scission rates, we found that the rate of $\mathrm{O}-\mathrm{H}$ bond scission was ca. $3 \sim 4$ orders of magnitude greater than $\mathrm{C}-\mathrm{H}$ bond scission on a stepped $\mathrm{Cu}(211)$ surface, in agreement with previous theoretical work $[32,33]$. The other transition metals in the volcano plots, materials such as $\mathrm{Ag}, \mathrm{Zn}, \mathrm{Co}$, 
$\mathrm{Ru}, \mathrm{Ni}$, and $\mathrm{Fe}$, are predicted to proceed through an initial $\mathrm{O}-\mathrm{H}$ bond scission, while materials such as $\mathrm{Pd}$ and $\mathrm{Pt}$ prefer to proceed through an initial $\mathrm{C}-\mathrm{H}$ bond scission. On $\mathrm{Rh}$ and $\mathrm{Au}$, the first dehydrogenation of $\mathrm{CH}_{3} \mathrm{OH}$ competitively proceeds through $\mathrm{O}-\mathrm{H}$ or $\mathrm{C}-\mathrm{H}$ bond cleavages. These results are consistent with previous theoretical studies [3437], which have investigated the reaction pathways for $\mathrm{CH}_{3} \mathrm{OH}$ dehydrogenation.

Comparing the TOFs of $\mathrm{CH}_{3} \mathrm{O}-\mathrm{H}$ bond scissions without (Fig. 2(a)) and with (Fig. 2(c)) the inclusion of adsorbate-adsorbate interactions, it was found that the maximum TOFs and the trend do not change after the interactions are included. The shape of the volcano with adsorbate-adsorbate interactions is different from the counterpart without interactions in that the former one becomes broad in the strong-binding region of $\mathrm{E}_{\mathrm{OH}}$ $\left(\mathrm{E}_{\mathrm{OH}}<-1 \mathrm{eV}\right)$ due to the change of $\mathrm{CH}_{3} \mathrm{O}^{*}$ coverage (see Fig. 3(b) and (e)). With the inclusion of adsorbate-adsorbate interactions, the decreased coverage of $\mathrm{CH}_{3} \mathrm{O} *$ produces an increased coverage of surface free sites, which can help the dissociation process; the shape of the volcano for TOFs of $\mathrm{CH}_{3} \mathrm{O}-\mathrm{H}$ bond scissions, accordingly, becomes broad in this area.
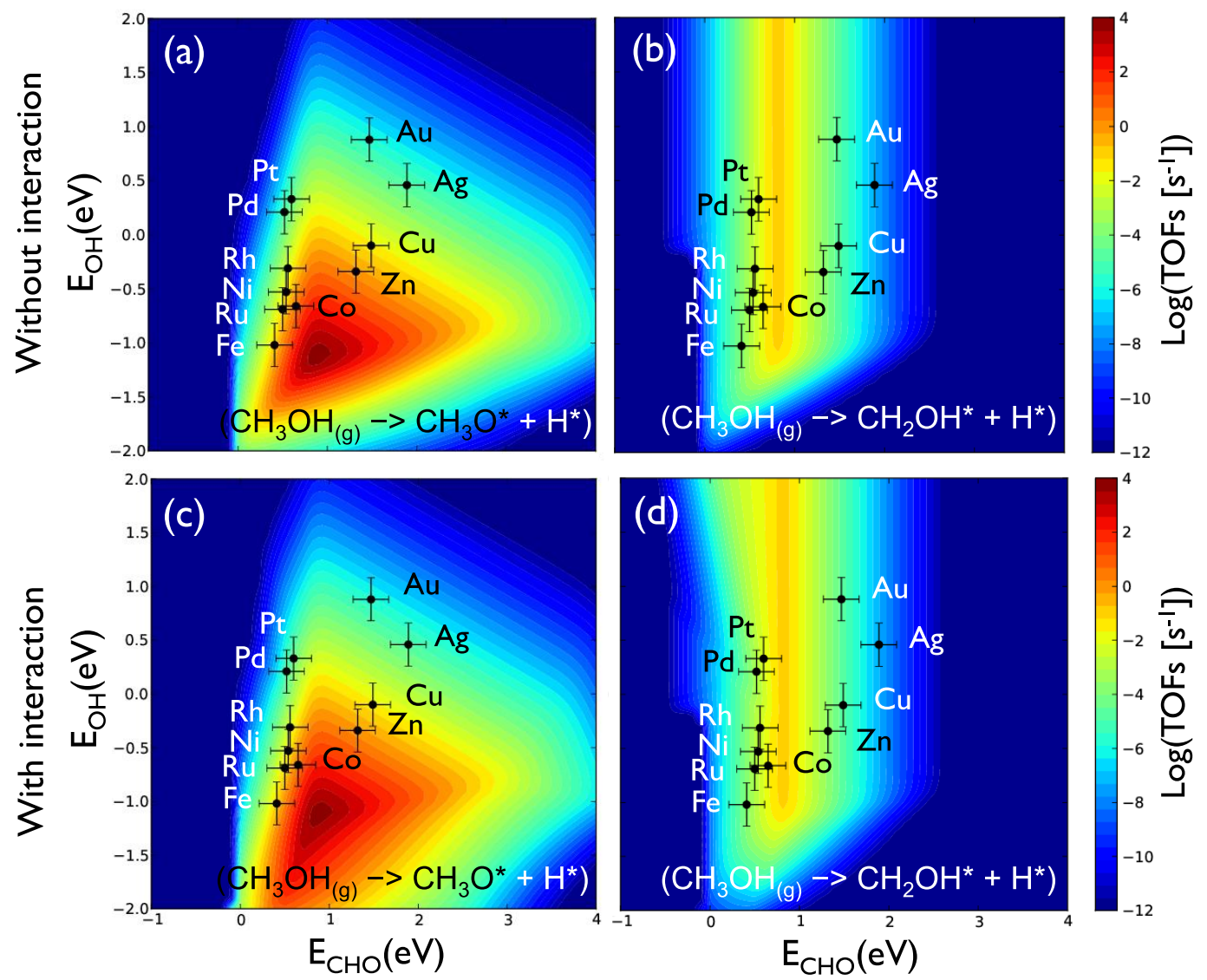

Fig. 2. Calculated turnover frequencies (TOFs) for $\mathrm{CH}_{3} \mathrm{OH}$ decomposition through $\mathrm{CH}_{3} \mathrm{O}-\mathrm{H}$ and $\mathrm{H}-\mathrm{CH}_{2} \mathrm{OH}$ bond scissions without (a and b) and with (c and d) the inclusion of adsorbate-adsorbate interactions as a function of $\mathrm{CHO}\left(\mathrm{E}_{\mathrm{CHO}}\right)$ and $\mathrm{OH}\left(\mathrm{E}_{\mathrm{OH}}\right)$ 
binding energies. $\mathrm{E}_{\mathrm{CHO}}$ and $\mathrm{E}_{\mathrm{OH}}$ for the (211) surfaces of selected transition metals are depicted along with error bars that indicate an estimated error of $0.2 \mathrm{eV}$ for $\mathrm{E}_{\mathrm{CHO}}$ and $\mathrm{E}_{\mathrm{OH}}$. Reaction conditions are $823 \mathrm{~K}$ and 1 bar with a gas composition of $95 \% \mathrm{CH}_{3} \mathrm{OH}, 1 \%$ $\mathrm{CH}_{2} \mathrm{O}, 1 \% \mathrm{CO}$, and $3 \% \mathrm{H}_{2}$.

Similarly, as can be seen from the TOFs for $\mathrm{H}-\mathrm{CH}_{2} \mathrm{OH}$ bond scissions without (Fig. 2(b)) and with (Fig. 2(d)) the inclusion of adsorbate-adsorbate interactions, the position of the TOF maximum and the trend is essentially unchanged after the interactions are included. Again, the shape of the volcano with interactions becomes broad in the region of $\mathrm{CHO}$ binding energy around $-0.5 \sim 0.5 \mathrm{eV}$ compared to the volcano without interactions, which is due to the change in $\mathrm{CO}^{*}$ (Fig. 3(a) and (d)) coverage. The inclusion of adsorbateadsorbate interactions decreases the coverages of $\mathrm{CO}^{*}$ (around $\mathrm{E}_{\mathrm{CHO}}=-0.5 \sim 0.5 \mathrm{eV}$ ), which results in an increased coverage of surface free sites and cause $\mathrm{H}-\mathrm{CH} 2 \mathrm{OH}$ bond scission to be dominant.

The predicted TOFs for the production of $\mathrm{CH}_{2} \mathrm{O}$ from $\mathrm{CH}_{3} \mathrm{OH}$ dehydrogenation with and without the inclusion of interactions are shown in Fig. 4(a) and (d), respectively. The volcano for $\mathrm{CH}_{2} \mathrm{O}$ production (Fig. 4(d)) is similar to a lower right portion of the volcano for $\mathrm{CH}_{3} \mathrm{O}-\mathrm{H}$ bond scission (Fig. 2(c)), indicating that the production of $\mathrm{CH}_{2} \mathrm{O}$ primarily proceeds through the $\mathrm{CH}_{3} \mathrm{O}-\mathrm{H}$ path via a $\mathrm{CH}_{3} \mathrm{O}$ intermediate. On the other hand, the volcano for $\mathrm{CO}$ production (Fig. 4(e)) is similar to the sum of the volcanoes for $\mathrm{H}-$ $\mathrm{CH}_{2} \mathrm{OH}$ (Fig. 2(d)) and $\mathrm{CH}_{3} \mathrm{O}-\mathrm{H}$ bond scissions, which demonstrates that $\mathrm{CO}$ production might be a combined contribution from these two paths. Unsurprisingly, the volcano for $\mathrm{H}_{2}$ production (Fig. 4(f)) corresponds to the sum of the volcanoes for $\mathrm{CH}_{2} \mathrm{O}$ and $\mathrm{CO}$ production. As shown in Fig. 4(d) (f), the TOFs of $\mathrm{CH}_{2} \mathrm{O}, \mathrm{CO}$, and $\mathrm{H}_{2}$ productions are quite small in the $\mathrm{E}_{\mathrm{CHO}}$ strong-binding region with $\mathrm{E}_{\mathrm{CHO}}=-0.5 \sim-1 \mathrm{eV}$, which can be attributed to the surface being almost completely blocked by $\mathrm{CO}$ in this area. Besides, Fig. 4(d) illustrates that in the upper left portion of volcano plot, the TOF for $\mathrm{CH}_{2} \mathrm{O}$ production is negligible due to $\mathrm{CH}_{2} \mathrm{O}$ being adsorbed from gas phase rather than desorbed in this area. 

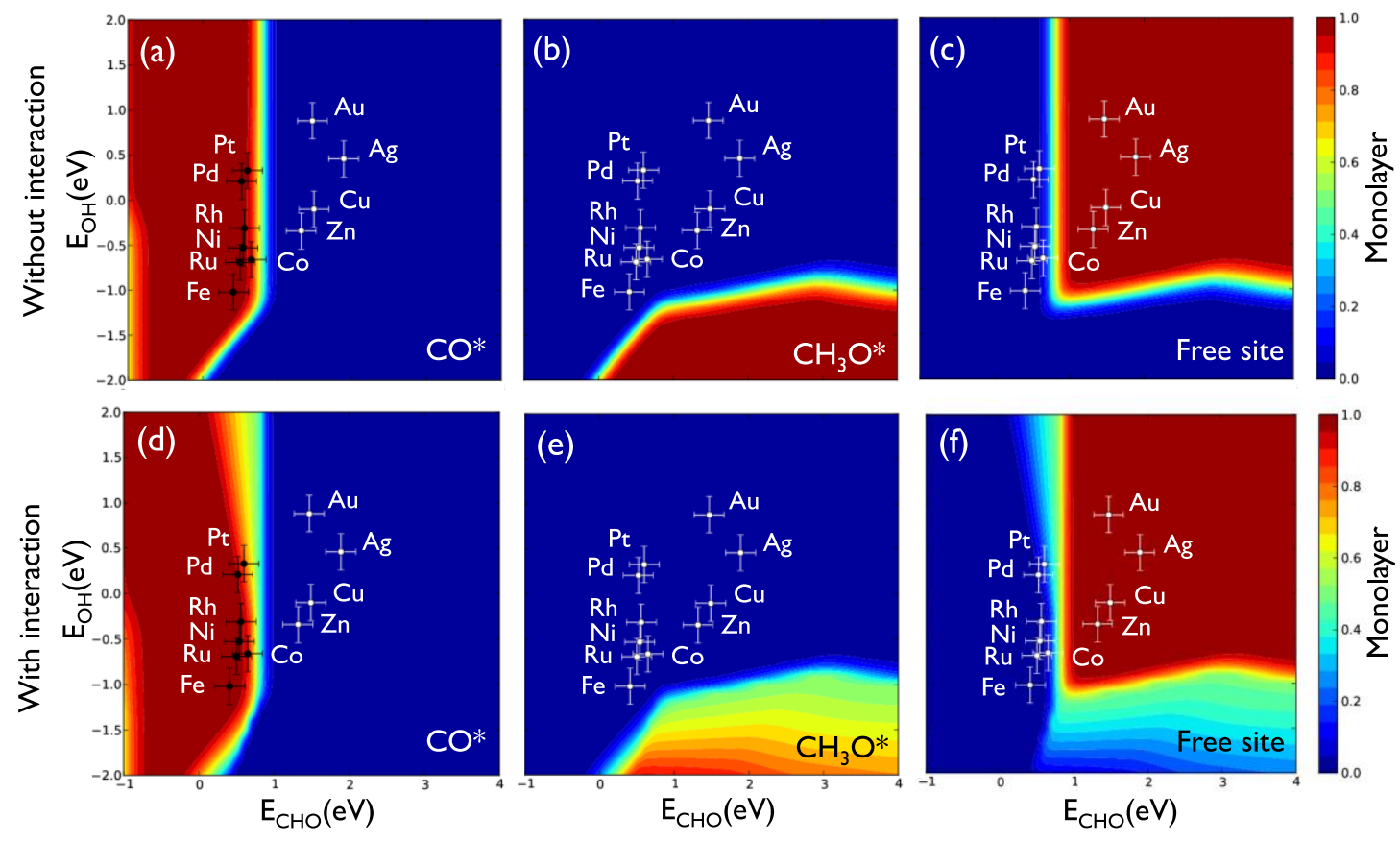

Fig. 3. Coverages of $\mathrm{CO}^{*}, \mathrm{CH}_{3} \mathrm{O}^{*}$, and surface free site as a function of $\mathrm{E}_{\mathrm{CHO}}$ and $\mathrm{E}_{\mathrm{OH}}$ as obtained from the solutions of the microkinetic model without $(a \sim c)$ and with $(d \sim f)$ the inclusion of adsorbate-adsorbate interactions. $\mathrm{E}_{\mathrm{CHO}}$ and $\mathrm{E}_{\mathrm{OH}}$ for the (211) surfaces of selected transition metals are depicted and the error bars indicate an estimated error of 0.2 $\mathrm{eV}$ for $\mathrm{E}_{\mathrm{CHO}}$ and $\mathrm{E}_{\mathrm{OH}}$. Reaction conditions are $823 \mathrm{~K}$ and 1 bar with a gas composition of $95 \% \mathrm{CH}_{3} \mathrm{OH}, 1 \% \mathrm{CH}_{2} \mathrm{O}, 1 \% \mathrm{CO}$, and $3 \% \mathrm{H}_{2}$. Small amounts of coverage for $\mathrm{COH}^{*}$ are in left bottom corner of volcano, which is shown in Fig. S2 of the supplementary information.

The predicted selectivity plots toward $\mathrm{CH}_{2} \mathrm{O}$ production with the inclusion of adsorbate-adsorbate interactions are given in Fig. 5(d). Selectivity is defined by the rate of $\mathrm{CH}_{2} \mathrm{O}$ formation divided by the sum of the rates of $\mathrm{CH}_{2} \mathrm{O}$ and $\mathrm{CO}$ formation. As shown in Fig. 5(d), most of the stepped (211) metallic surfaces such as $\mathrm{Au}, \mathrm{Pt}, \mathrm{Pd}, \mathrm{Rh}, \mathrm{Ru}$, $\mathrm{Ni}, \mathrm{Fe}$, and $\mathrm{Co}$ are located in the region of low selectivity towards $\mathrm{CH}_{2} \mathrm{O}$, which means that the majority of products are predicted to be $\mathrm{CO}$ rather than $\mathrm{CH}_{2} \mathrm{O}$. Inspection of Fig. 5(a) and (b) reveals that $\mathrm{Au}, \mathrm{Pt}, \mathrm{Pd}, \mathrm{Rh}, \mathrm{Ru}, \mathrm{Ni}, \mathrm{Fe}$, and $\mathrm{Co}$, have higher TOFs for $\mathrm{CH}_{2} \mathrm{O}$ dehydrogenation compared to $\mathrm{CH}_{2} \mathrm{O}$ desorption, which is consistent with the low selectivity toward $\mathrm{CH}_{2} \mathrm{O}$ that we found on the corresponding stepped (211) surfaces. These results suggest the intriguing possibility of improving the selectivity towards $\mathrm{CH}_{2} \mathrm{O}$ production by tuning the reactivity of the metallic catalyst. Since the selectivities toward $\mathrm{CH}_{2} \mathrm{O}$ production on $\mathrm{Zn}, \mathrm{Cu}$, and $\mathrm{Ag}$ surfaces are located in the boundary between the high and low selectivity regions, we expect that $\mathrm{Zn}, \mathrm{Cu}$, and $\mathrm{Ag}$ might be better candidates for tuning the reactivity. Two possible strategies are: (1) modifying the electronic structure of the metal by forming bimetallic alloys, or (2) changing the coordination number of metal by using the (111) facet. We demonstrate the first 
possibility in the next section, while the latter possibility is explored in a forthcoming work [38].
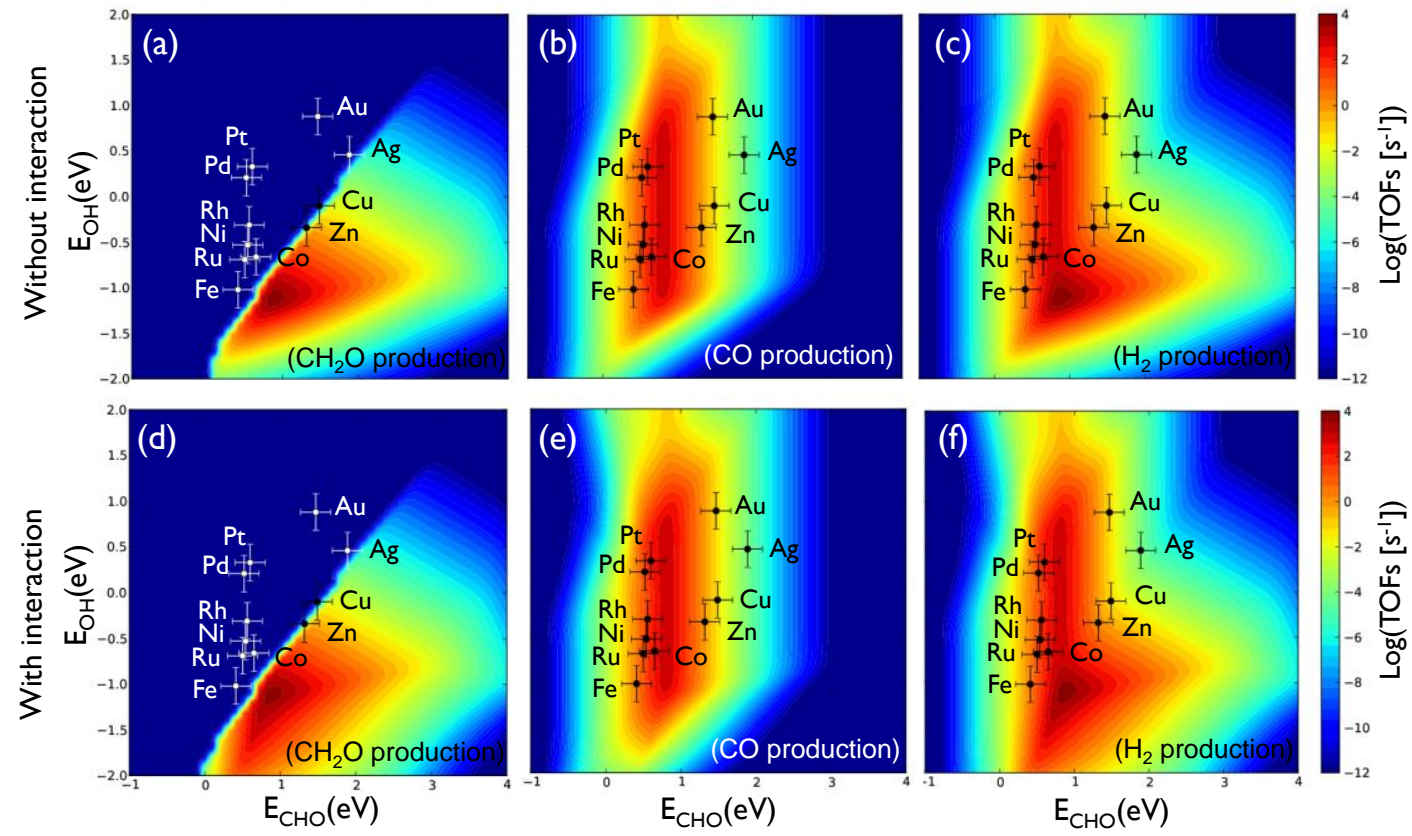

Fig. 4. Calculated TOFs for the production of $\mathrm{CH}_{2} \mathrm{O}, \mathrm{CO}$ and $\mathrm{H}_{2}$ from $\mathrm{CH}_{3} \mathrm{OH}$ dehydrogenation without $(\mathrm{a} \sim \mathrm{c})$ and with $(\mathrm{d} \sim \mathrm{f})$ inclusion of adsorbate-adsorbate interactions as a function of $\mathrm{E}_{\mathrm{CHO}}$ and $\mathrm{E}_{\mathrm{OH}}$. $\mathrm{E}_{\mathrm{CHO}}$ and $\mathrm{E}_{\mathrm{OH}}$ for the (211) surfaces of selected transition metals are depicted and the error bars indicate an estimated error of 0.2 $\mathrm{eV}$ for $\mathrm{E}_{\mathrm{CHO}}$ and $\mathrm{E}_{\mathrm{OH}}$. Reaction conditions are $823 \mathrm{~K}$ and 1 bar with a gas composition of $95 \% \mathrm{CH}_{3} \mathrm{OH}, 1 \% \mathrm{CH}_{2} \mathrm{O}, 1 \% \mathrm{CO}$, and $3 \% \mathrm{H}_{2}$.

\subsection{Alloy Screening}

We have screened a large number of transition metal alloys based on their predicted rates and selectivities from our microkinetic model, estimated their stabilities and prices, and finally propose several candidates for the dehydrogenation of $\mathrm{CH}_{3} \mathrm{OH}$ process. Two terminations of the $\mathrm{A}_{3} \mathrm{~B}$-type alloy (where $\mathrm{A}$ and $\mathrm{B}$ are two different transition metals), $\mathrm{AA}$ and $\mathrm{AB}$, are considered in the screening process (shown in Fig. S2 of the supplementary information). The estimated formation energies, calculated binding energies of $\mathrm{CHO}$ and $\mathrm{OH}$, predicted rates of $\mathrm{CH}_{2} \mathrm{O}$ production, and price of considered alloys are summarized in Table $\mathrm{S} 4$ of the supplementary information. 

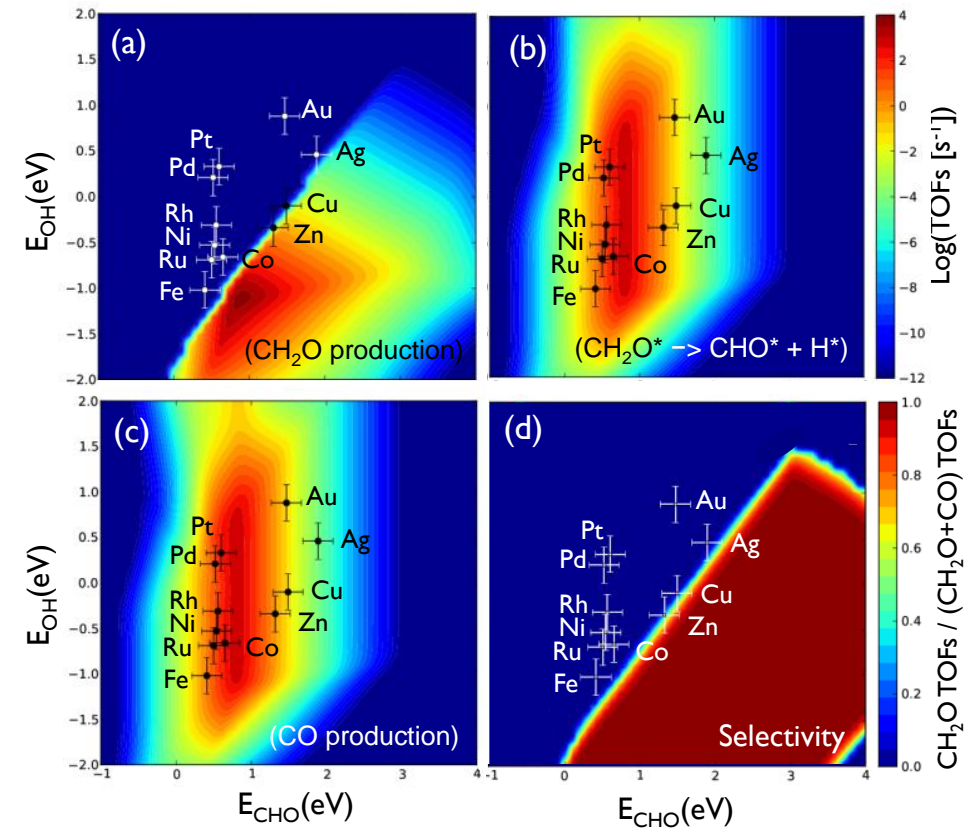

Fig. 5. Calculated TOFs for (a) $\mathrm{CH}_{2} \mathrm{O}$ production, (b) $\mathrm{H}-\mathrm{CHO}$ bond scission, and (c) $\mathrm{CO}$ production as well as (d) selectivity toward $\mathrm{CH}_{2} \mathrm{O}$ production with inclusion of adsorbateadsorbate interactions as a function of $\mathrm{E}_{\mathrm{CHO}}$ and $\mathrm{E}_{\mathrm{OH}}$. $\mathrm{E}_{\mathrm{CHO}}$ and $\mathrm{E}_{\mathrm{OH}}$ for the (211) surfaces of selected transition metals are depicted and the error bars indicate an estimated error of $0.2 \mathrm{eV}$ for $\mathrm{E}_{\mathrm{CHO}}$ and $\mathrm{E}_{\mathrm{OH}}$. Reaction conditions are $823 \mathrm{~K}$ and 1 bar with a gas composition of $95 \% \mathrm{CH}_{3} \mathrm{OH}, 1 \% \mathrm{CH}_{2} \mathrm{O}, 1 \% \mathrm{CO}$, and $3 \% \mathrm{H}_{2}$.

\subsubsection{Stability filter}

As described in reference [39], the stable formation of an intermetallic compound composed of two metallic elements is described by the alloy's formation energy, $E_{f}$, which can be defined as:

$E_{f}=E_{\text {alloy }}-N_{A} E_{A(\text { bulk })}-N_{B} E_{B(\text { bulk })}$

where $E_{f}$ is the formation energy, $E_{\text {alloy }}$ is the DFT-calculated energy of the metal alloy, $N_{i}$ and $E_{i(b u l k)}$ are the molar ratios and the DFT calculated energies, respectively, of the individual metal, $i$. According to this definition, the more negative the value, the more stable the alloy. For the purposes of the present analysis, only alloys with formation energy less than $0 \mathrm{eV}$ per unit cell were considered to be potentially stable (approximately 440 alloys). The estimated formation energies are listed in Table S4 of the supplementary information.

\subsubsection{Activity and selectivity filters}


As we have shown, the binding energies of $\mathrm{CHO}$ and $\mathrm{OH}$ are valid descriptors for predicting the reaction rate and selectivity for anhydrous $\mathrm{CH}_{2} \mathrm{O}$ production. The binding energies of $\mathrm{CHO}$ and $\mathrm{OH}$ on these thermodynamically stable stepped (211) alloys were also calculated using DFT and given in Table S4 of the supplementary information. Now we proceed to screen these stable transition metal alloys based on the established volcano from microkinetic modeling, illustrated in Fig. 6(a). As shown in Fig. 6(a), the alloys can be divided into two categories based on both activity and selectivity: (1) the alloys with the turnover frequencies of $\mathrm{CH}_{2} \mathrm{O}$ production smaller than $10^{-1} \mathrm{~s}^{-1}$ or the selectivity toward $\mathrm{CH}_{2} \mathrm{O}$ smaller than 0.7 (denoted with a black circle); (2) the alloys with the turnover frequencies of $\mathrm{CH}_{2} \mathrm{O}$ production larger than $10^{-1} \mathrm{~s}^{-1}$ and the selectivity toward $\mathrm{CH}_{2} \mathrm{O}$ larger than 0.7 (denoted with a white star). After filtering by activity and selectivity, approximately 90 alloys (denoted by white stars) are predicted to be the suitable catalysts for anhydrous $\mathrm{CH}_{2} \mathrm{O}$ production. These approximately 90 alloys further are screened by price in next section.

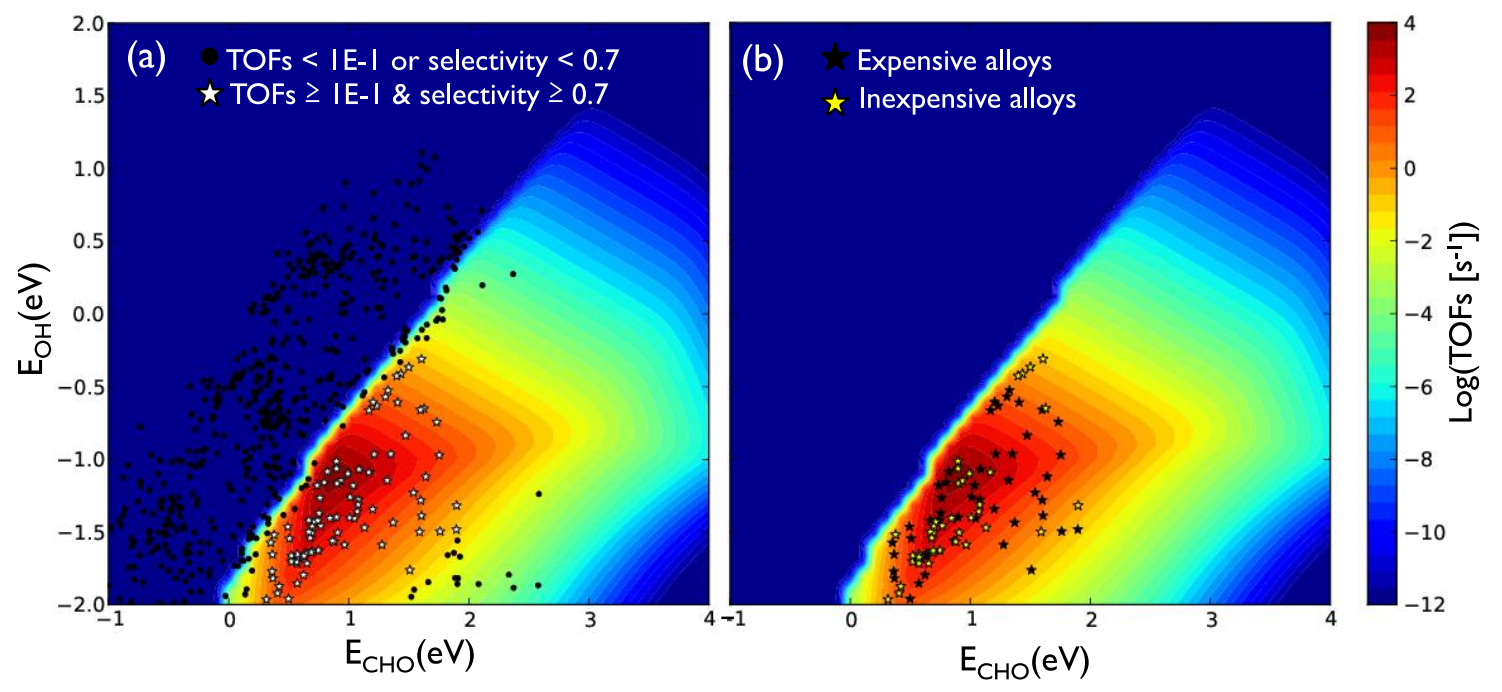

Fig. 6. Alloys screening from activity, selectivity, and costs with adsorbate-adsorbate interactions: (a) Alloys are divided into two categories based on both activity and selectivity: (1) alloys with low activity or selectivity (TOFs $<10^{-1} \mathrm{~s}^{-1}$ or selectivity $<0.7$, black circle) and (2) alloys with high activity and selectivity (TOFs $\geq 10^{-1} \mathrm{~s}^{-1}$ and selectivity $\geq 0.7$, white star); (b) alloys are divided into two categories based on the material costs of their component metals: (1) expensive alloys (cost $\geq \$ 2000 \mathrm{~kg}^{-1}$, black star) and (2) inexpensive alloys (cost $<\$ 2000 \mathrm{~kg}^{-1}$, yellow star). The volcanoes for the production of $\mathrm{CH}_{2} \mathrm{O}$ under reaction conditions are $823 \mathrm{~K}$ and 1 bar with a gas composition of $95 \% \mathrm{CH}_{3} \mathrm{OH}, 1 \% \mathrm{CH}_{2} \mathrm{O}, 1 \% \mathrm{CO}$, and $3 \% \mathrm{H}_{2}$.

\subsubsection{Price filter}


The price of the catalyst is always an important consideration in industry due to the need for large-scale production. In this section, we have used simple interpolation estimation to calculate the price of the metallic alloys, $A_{3} B$, composed by $A$ and $B$ elements. Reference prices of pure metals were taken from website chemicool [40] and the estimated prices for $\mathrm{A}_{3} \mathrm{~B}$ alloys were given in Table $\mathrm{S} 4$ of the supplementary information. We assume that the estimated prices of each alloy only depend on the composition ration of $\mathrm{A}$ and $\mathrm{B}$ elements, while we do not consider the costs for preparation. To exclude alloys containing relatively expensive metals, we set the cutoff price of alloys as $\$ 2000 \mathrm{~kg}^{-1}$, illustrated in Fig. 6(b). Black stars denote the considered alloys with prices higher than $\$ 2000 \mathrm{~kg}^{-1}$, while yellow stars in the volcano plot denote the alloys with prices lower than $\$ 2000 \mathrm{~kg}^{-1}$. After screening by rate, selectivity, and price, only 39 alloys were left in the volcano plot, listed in Table 1. It should be noted that other elementary reaction steps steps than what we consider in this analysis might influence the reaction over some of these alloys. For instance, the direct $\mathrm{C}-\mathrm{O}$ bond scission might be relevant over highly oxophilic metals.

From our prediction of alloys screening for the anhydrous $\mathrm{CH}_{2} \mathrm{O}$ production from $\mathrm{CH}_{3} \mathrm{OH}$, we propose several bimetallic alloy candidates, which can provide experimentalists an alternative for future research in to catalytic $\mathrm{CH}_{3} \mathrm{OH}$ dehydrogenation to produce anhydrous $\mathrm{CH}_{2} \mathrm{O}$.

Table 1: The screened alloys with the TOFs of $\mathrm{CH}_{2} \mathrm{O}$ production $\geq 10^{-1} \mathrm{~s}^{-1}$, selectivity toward $\mathrm{CH}_{2} \mathrm{O}$ production $\geq 0.7$, and price $<\$ 2000 \mathrm{~kg}^{-1}$.

\begin{tabular}{ccccc}
\hline $\mathrm{Co}_{3} \mathrm{Zr} / \mathrm{AA}, \mathrm{AB}$ & $\mathrm{Zn}_{3} \mathrm{~V} / \mathrm{AA}$ & $\mathrm{Cd}_{3} \mathrm{Y} / \mathrm{AB}$ & $\mathrm{Pb}_{3} \mathrm{Sc} / \mathrm{AB}$ & $\mathrm{Zr}_{3} \mathrm{~Pb} / \mathrm{AB}$ \\
$\mathrm{Tl}_{3} \mathrm{La} / \mathrm{AA}, \mathrm{AB}$ & $\mathrm{Zn}_{3} \mathrm{Y} / \mathrm{AA}$ & $\mathrm{Co}_{3} \mathrm{~W} / \mathrm{AB}$ & $\mathrm{Pb}_{3} \mathrm{Y} / \mathrm{AB}$ & $\mathrm{Zr}_{3} \mathrm{Sb} / \mathrm{AB}$ \\
$\mathrm{Fe}_{3} \mathrm{Al} / \mathrm{AA}$ & $\mathrm{Zn}_{3} \mathrm{Zr} / \mathrm{AA}$ & $\mathrm{Cu}_{3} \mathrm{Al} / \mathrm{AB}$ & $\mathrm{Sb}_{3} \mathrm{Y} / \mathrm{AB}$ & $\mathrm{Zr}_{3} \mathrm{Sn} / \mathrm{AB}$ \\
$\mathrm{Zn}_{3} \mathrm{Fe} / \mathrm{AA}$ & $\mathrm{Ag}_{3} \mathrm{Al} / \mathrm{AB}$ & $\mathrm{Ga}_{3} \mathrm{Hf} / \mathrm{AB}$ & $\mathrm{Sn}_{3} \mathrm{Sc} / \mathrm{AB}$ & \\
$\mathrm{Zn}_{3} \mathrm{Hf} / \mathrm{AA}$ & $\mathrm{Ag}_{3} \mathrm{Y} / \mathrm{AB}$ & $\mathrm{Hf}_{3} \mathrm{Bi} / \mathrm{AB}$ & $\mathrm{Sn}_{3} \mathrm{Y} / \mathrm{AB}$ & \\
$\mathrm{Zn}_{3} \mathrm{Mo} / \mathrm{AA}$ & $\mathrm{Al}_{3} \mathrm{Cu} / \mathrm{AB}$ & $\mathrm{Hf}_{3} \mathrm{Sb} / \mathrm{AB}$ & $\mathrm{Sn}_{3} \mathrm{Zr} / \mathrm{AB}$ & \\
$\mathrm{Zn}_{3} \mathrm{Nb} / \mathrm{AA}$ & $\mathrm{Bi}_{3} \mathrm{La} / \mathrm{AB}$ & $\mathrm{Hf}_{3} \mathrm{Sn} / \mathrm{AB}$ & $\mathrm{Tl}_{3} \mathrm{Sc} / \mathrm{AB}$ & \\
$\mathrm{Zn}_{3} \mathrm{Ni} / \mathrm{AA}$ & $\mathrm{Bi}_{3} \mathrm{Sc} / \mathrm{AB}$ & $\mathrm{Ni}_{3} \mathrm{~V} / \mathrm{AB}$ & $\mathrm{Tl}_{3} \mathrm{Y} / \mathrm{AB}$ & \\
$\mathrm{Zn}_{3} \mathrm{Ti} / \mathrm{AA}$ & $\mathrm{Bi}_{3} \mathrm{Y} / \mathrm{AB}$ & $\mathrm{Pb}_{3} \mathrm{La} / \mathrm{AB}$ & $\mathrm{Zr}_{3} \mathrm{Bi} / \mathrm{AB}$ & \\
\hline
\end{tabular}

\section{Conclusions}

We have demonstrated that binding energies of reaction intermediates and transition state energies for each elementary reaction can be accurately scaled with only two descriptors, $\mathrm{E}_{\mathrm{CHO}}$ and $\mathrm{E}_{\mathrm{OH}}$, for dehydrogenation of $\mathrm{CH}_{3} \mathrm{OH}$ on stepped (211) surfaces. 
Based on these two descriptors, a microkinetic model performed with piecewise adsorbate-adsorbate interactions is used to estimate the reaction rates and selectivities. Our results show that the maximum TOFs of $\mathrm{CH}_{2} \mathrm{O}$ production do not change, while the shape of the volcano becomes broad after the interactions are included due to the change of coverage for $\mathrm{CH}_{3} \mathrm{O}^{*}$ and surface free sites. Most of the stepped (211) metallic surfaces such as $\mathrm{Au}, \mathrm{Pt}, \mathrm{Pd}, \mathrm{Rh}, \mathrm{Ru}, \mathrm{Ni}, \mathrm{Fe}$, and $\mathrm{Co}$ are located in the region of low selectivity towards $\mathrm{CH}_{2} \mathrm{O}$, while $\mathrm{Zn}, \mathrm{Cu}$, and $\mathrm{Ag}$ are located near the region of boundary between high and low selectivities. Based on the estimated microkinetic model on the stepped (211) pure metals, we use two descriptors $\left(\mathrm{E}_{\mathrm{CHO}}\right.$ and $\left.\mathrm{E}_{\mathrm{OH}}\right)$ to predict the rates and selectivities, as well as estimate the stabilities and prices for a large number of transition metal alloys. Finally, we propose several candidates for the production of anhydrous formaldehyde.

\section{Acknowledgments}

The authors thank the U.S. Department of Energy's Office of Basic Energy Science for

support through an Early Career grant and support to the SUNCAT Center for Interface Science and Catalysis at SLAC/Stanford.

\section{References}

[1] G. Reuss, W. Disteldorf, O. Grundler, A. Hilt, I.F. Ullmann, W. Gerhartz, Y.S. Yamamoto, F.T. Campbell, R. Pfefferkorn, J.F. Rounsaville (Eds.), Ullmann's Encyclopedia of Industrial Chemistry, fifth ed., VCH, Deerfield Beach, FL, USA, 1985, p.619.

[2] M.V. Twigg, Catalyst Handbook, Wolfe Publishing Ltd., London, 1989, p.490.

[3] A. Meyer, A. Renken, Chem. Eng. Technol. 13 (1990) 145-149.

[4] H. Gerberich, G.C. Seaman, Kirk-Othmer Encyclopedia of Chemical Technology, fifth ed., John Wiley \& Sons, New York, 2004.

[5] S. Su, P. Zaza, A. Renken, Chem. Eng. Technol. 17 (1994) 34-40.

[6] R.S. Aries, US Patent 2953 602, Mitsubishi Gas Chemical Company, Inc., 1960.

[7] S. Ruf, A. May, G. Emig, Appl. Catal. A 213 (2001) 203-215.

[8] K. Takagi, Y. Morikawa, T. Ikawa, Chem. Lett. 14 (1985) 527-530.

[9] T. Yamamoto, A. Shimoda, T. Okuhara, M. Misono, Chem. Lett. 17 (1988) 273276.

[10] A. Mušič, J. Batista, J. Levec, Appl. Catal. A 165 (1997) 115-131.

[11] Y. Dong, W.-L. Dai, J.-L. Li, J.-F. Deng, Chem. Lett. 30 (2001) 534-535.

[12] L.-P. Ren, W.-L. Dai, Y. Cao, K.-N. Fan, Catal. Lett. 85 (2003) 81-85.

[13] L.-P. Ren, W.-L. Dai, Y. Cao, H. Li, K. Fan, Chem. Commun. 24 (2003) 30303031 . 
[14] L.-P. Ren, W.-L. Dai, X.-L. Yang, Y. Cao, H. Li, K.-N. Fan, Appl. Catal. A: Gen. 273 (2004) 83-88.

[15] M.J. Lippits, R.R.H. Boer Iwema, B.E. Nieuwenhuys, Catal. Today. 145 (2009) 27-33.

[16] C. Maldonado, J.L.G. Fierro, G. Birke, E. Martínez, P. Reyes, J. Chil. Chem. Soc. 55 (2010) 506-510.

[17] K. Hashimoto, N. Toukai, J. Mol. Catal. A: Chem. 145 (1999) 273-280.

[18] M. Akyama, T. Yao, JP Appl. No. 3-014532, Sumitomo Metal Industries, 1991.

[19] A.C. Lausche, J.S. Hummelshøj, F. Abild-Pedersen, F. Studt, J.K. Nørskov, J. Catal. 291 (2012) 133-137.

[20] T.S. Khan, H. Falsig, S. Wang, W. Guo, S.H. Broderson, J. Schiøtz, S. Dahl, T. Bligaard, to be submitted for publication (2015).

[21] CatApp, <http://suncat.slac.stanford.edu/catapp>

[22] J.S. Hummelshøj, F. Abild-Pedersen, F. Studt, T. Bligaard, J.K. Nørskov, Angew. Chem. Int. Ed. 51 (2012) 272-274.

[23] The Dacapo plane wave pseudopotential code is available as open source software, $<$ Http://Wiki.Fysik.Dtu.Dk/Dacapo>

[24] B. Hammer, L.B. Hansen, J.K. Nørskov, Phys. Rev. B. 59 (1999) 7413-7421.

[25] J.J. Mortensen, K. Kaasbjerg, S.L. Frederiksen, J.K. Nørskov, P. Sethna, K.W. Jacobsen, Phys. Rev. Lett. 95 (2005) 216401.

[26] J. Wellendorff, K.T. Lundgaard, A. Møgelhøj, V. Petzold, D.D. Landis, J.K. Nørskov, T. Bligaard, K.W. Jacobsen, Phys. Rev. B. 85 (2012) 235149.

[27] F. Studt, F. Abild-Pedersen, J.B. Varley, J.K. Nørskov, Catal. Lett. 143 (2013) 7173.

[28] W. Dai, L. Ren, Handbook of Heterogeneous Catalysis, 2008, pp. 3256-3265.

[29] A.C. Lausche, A.J. Medford, T.S. Khan, Y. Xu, T. Bligaard, F. Abild-Pedersen, J.K. Nørskov, F. Studt, J. Catal. 307 (2013) 275-282.

[30] L.C. Grabow, B. Hvolbæk, J.K. Nørskov, Top. Catal. 53 (2010) 298-310.

[31] M. Andersson, F. Abild-Pedersen, I.N. Remediakis, T. Bligaard, G. Jones, J. Engbæk, O. Lytken, S. Horch, J.H. Nielsen, J. Sehested, J. Catal., 255 (2008) 619.

[32] C.J. Jiang, D.L. Trimm, M.S. Wainwright, N.W. Cant, Appl. Catal. A: Gen. 97 (1993) 145-158.

[33] D. Mei, L. Xu, G. Henkelman, J. Phys. Chem. C. 113 (2009) 4522-4537.

[34] G.-C. Wang, Y.-H. Zhou, Y. Morikawa, J. Nakamura, Z.-S. Cai, X.-Z. Zhao, J. Phys. Chem. B. 109 (2005) 12431-12442.

[35] R. Jiang, W. Guo, M. Li, D. Fu, H. Shan, J. Phys. Chem. C. 113 (2009) 41884197.

[36] R. Jiang, W. Guo, M. Li, X. Lu, J. Yuan, H. Shan, Phys. Chem. Chem. Phys. 12 (2010) 7794-7803. 
[37] R. Jiang, W. Guo, M. Li, H. Zhu, L. Zhao, X. Lu, H. Shan, J. Mol. Catal. A: Chem. 344 (2011) 99-110.

[38] H.-J. Li, A.C. Lausche, C. Shi, F. Studt, T. Bligaard, to be submitted for publication (2015).

[39] Y. Xu, A.C. Lausche, S. Wang, T.S. Khan, F. Abild-Pedersen, F. Studt, J.K. Nørskov, T. Bligaard, New J. Phys. 15 (2013) 125021.

[40] chemicool, <www.chemicool.com> 